Наумова Лариса Николаевна, кандидат философских наук, доцент, доцент кафедры режиссуры телевидения. Киевский национальный университет театра, кино и телевидения имени И. К. Карпенко-Карого, Киев

Larysa Naymova, Ph.D in Philosophical Sciences, Associate Professor, Associate Professor of television directing Department. Kyiv National I. K. Karpenko-Karyi Theatre, Cinema and Television University, Kyiv

\title{
ТЕОРІЯ ЕКРАННОЇ РЕЖИСУРИ ВОЛОДИМИРА ГОРПЕНКА В КОНТЕКСТІ ДІЯЛЬНОСТІ УКРАЇНСЬКОЇ ШКОЛИ ТЕОРІЇ РЕЖИСУРИ ЕКРАННИХ МИСТЕЦТВ
}

\begin{abstract}
Анотація. Стаття присвячена дослідженню феномену школи теорії режисури екранних мистецтв, яка виникла і плідно працювала в Київському університеті театрального, кіно і телевізійного мистецтва ім. І. Карпенка-Карого впродовж 1980-1990 років. Вона стала грунтовною базою для підготовки режисерів-практиків, педагогів і теоретиків екранних мистецтв. Особливе місце у цій школі належало теоретику екранної режисури, педагогу Володимирові Горпенку. Його праці з теорії режисури екранних мистецтв презентують окремі напрями діяльності школи.

Ключові слова: школа теорії режисури екранних мистецтв, теорія режисури, екранні мистецтва, Володимир Горпенко, режисура.
\end{abstract}

Постановка проблеми. Теоретичну і педагогічну діяльність Володимира Горпенка з надзвичайно цінним науковим доробком на ниві теорії екранної режисерської творчості слід розглядати в безпосередньому зв'язку з розвитком української школи теорії режисури екранних мистецтв, яка дивовижним чином виникла і розвинулась упродовж 1980-1990 років як самобутне самостійне явище на кафедрі режисури телебачення тодішнього Київського державного інституту театрального мистецтва, кіно і телебачення імені Івана Карпенка-Карого (тепер Київського національного університету театру, кіно і телебачення імені I. К. Карпенка-Карого), на кінофакультеті.

Під «школою» будемо розуміти вироблену комплексну систему набування та засвоєння знань, досвіду, навичок, а також сам набутий дос- від, практичні знання, в тому числі практичні прийоми, зрештою оволодіння та оперування знаннями і навичками, що здатне провокувати формування напряму в науці та мистецтві у цьому разі. Хоча українська школа теорії режисури екранних мистецтв розуміється нами насамперед як школа теоретична, наукова, все ж, з огляду на особливості іiі формування і функціонування в Київському державному інституті театрального мистецтва, кіно і телебачення імені Івана Карпенка-Карого як бази підготовки практиків екранних мистецтв, не слід виключати іiї мистецького і наукового значення. Проте саме у межах школи чи не вперше в Україні відбулася систематизація попереднього теоретичного і практичного досвіду та сформувався комплексний підхід до режисури екранних мистецтв як до теоретичної галузі, а в контексті 
педагогіки - відбулося відповідне утворення низки фахових теоретичних дисциплін, що мали забезпечити підготовку практиків екранних мистецтв.

Засади теорії режисури Володимира Горпенка мають міцні і закономірні зв'язки з теоретичними пошуками інших представників цієї школи (Віктора Кісіна, Вадима Чубасова та інших). Не останню роль в діяльності школи відіграє педагогічний метод і практична робота зі студентами.

Аналіз досліджень $\boldsymbol{i}$ публікацій. Імовірно, версія існування української школи теорії режисури екранних мистецтв спершу може викликати здивування. Проте факт існування явища школи насправді уже давно не має викликати сумніву, оскільки в поодиноких проявах і персоналіях, опосередковано, уже достатньо засвідчений режисерами-практиками, педагогами і учнями Василем Вітром, Тетяною Дейнегіною, Григорієм Десятником, Василем Образом, Романом Ширманом та ін. (Кол. монограф. Пам'ять. Майстер майстрів - Вадим Львович Чубасов, 2020), а також у певному ключі, $з$ точки зору діяльності окремих її представників, достатньо проаналізований і досліджений українськими науковцями Вадимом Скуратівським, Володимиром Горпенком, Олександром Безручком, Сергієм Марченком, Катериною Юдовою-Романовою, Іриною Довженко та багатьма іншими. Важливий і великий внесок у роботі з вивчення й популяризації окремих представників школи і їх педагогічної та наукової діяльності зробив Олександр Безручко, ставши упорядником колективних монографій, присвячених Вадимові Чубасову (Кол. монограф. Вадим Чубасов: режисер, науковеиь, педагог, 2014) та Віктору Кісіну (Кол. монограф. В. Б. Kiсін: режисер, науковещь, педагог, 2016-2021). Дослідникові належать також численні публікації про діяльність окремих представників школи. Деякі наші попередні розвідки чи не впритул підходять до теми існування школи (Наумова, 2011; 2016; 2019), хоча безпосередньо про українську школу теорії режисури екранних мистецтв поки що в жодній з них не ішлося.

Наукова і педагогічна діяльність Володимира Горпенка вивчалась Іриною Зубавіною, Сергієм Тримбачем, Олександром Безручком та іншими. У низці присвячених цій темі публікацій О. Безручко зосереджується на питаннях особистого формування та становлення В. Горпенка як педагога і науковця. Ці статті дають можливість зробити висновки про особливість і природу наукового та педагогічного методу В. Горпенка.
Отже, існують, хоч і розрізнені, однак достатньо серйозні грунтовні дослідження про діяльність окремих представників школи: статті у фахових наукових і науково-популярних виданнях, колективні монографії тощо. Та, на жаль, системних, загальних досліджень 3 вивчення цілісного явища виникнення і розвитку української школи теорії режисури екранних мистецтв досі немає. Тож і ця школа теорії екранної режисури, як цілісне явище, залишається досі не визначеною, а відтак і широко не відомою.

Складність дослідження школи виникає, імовірно, через переважно практичну і педагогічну діяльність ії представників. Друкованих теоретичних праць, як задокументованих свідчень існування школи, вийшло небагато. Це праці Віктора Кісіна «Режисура як мистецтво та професія» (Кісін, 1998), окремі розвідки у наукових виданнях (Кісін, 1983), підручник Вадима Чубасова «Вступ до спеціальності “Кінотелемистецтво”» (Чубасов, 2005), а також значна кількість методичних посібників та навчально-методичної документації. Значне місце у цьому доробку посідає навчальний фільм Вадима Чубасова 1989 року «С. М. Ейзенштейн: уроки монтажу» (Марченко, 2014). Переважаюча кількість опублікованих праць 3 теорії режисури екранних мистецтв належить саме Володимирові Горпенку. Загалом ним написано 30 книг різного періоду видання (Безручко, 2017, c. 359), та нас більше цікавить період існування i діяльності української школи теорії режисури екранних мистецтв. На цей час припадають найважливіші теоретичні праці. Передусім це 5-томна «Архітектоніка фільму» (Горпенко, 2000, в 5 т), 2-томне в 4 частинах дослідження про природу кольору «Колір» (Горпенко, 1995) підручники 3 монтажу, драматургії, композиції, пластичного вирішення екранного твору тощо та багато інших розвідок.

Усі праці представників школи, що побачили світ, $є$ надзвичайно цінним матеріалом. Адже усі вони є результатом багаторічної копіткої роботи представників школи, зваженим узагальненням їх теоретичних розмірковувань, підкріплених експериментальним практичним досвідом у співпраці 3 колегами і студентами в ході навчального процесу. Теоретичні праці представників цієї школи широко відомі як у колі теоретиків і науковців, так і у колах фахівців-практиків. Ці праці є теоретичними і практичними підручниками 3 підготовки фахівців у сфері режисерської творчості. Отже, праці представників школи по десятиліттях іiї існування не зникли і не забуті, а плідно застосо- 
вуються в процесі навчання і слугують базовим матеріалом для подальших теоретичних розвідок.

Актуальність дослідження. Таким чином, явище, що мало місце на кафедрі режисури телебачення Київського державного інституту театру, кіно і телебачення імені Івана Карпенка-Карого впродовж 1980-1990 років певно, вже можна і навіть на сьогодні необхідно означити саме як школу, українську школу теорії режисури екранних мистецтв. Справді, існує нагальна потреба одного разу нарешті означити це явище і вивести у дискурс загального теоретичного обігу, аби не втратити його сутнісну цілісність і багатогранність проявів.

Надзвичайно важливо, що ця школа теорії режисури екранних мистецтв виникла як специфічне самобутнє місцеве, тобто українське явище. Підгрунтям її став весь комплекс тогочасних науково-теоретичних надбань у сферах історії і теорії видовищної творчості; історії, теорії і педагогіки театру, кіно і телебачення; праці з теорії екранних і суміжних мистецтв, психології, теорії режисури тощо. Весь цей матеріал був упродовж багатьох років практичної викладацької діяльності переосмислений представниками школи у власну струнку систему.

Оскільки, говорячи про українську школу теорії режисури екранних мистецтв, ми звертаємо увагу саме на українські надбання у цій сфері, то, звичайно, не виникає жодних сумнівів щодо актуальності й доречності вивчення даної теми, принаймні хоча б перших спроб на цьому шляху. Адже вивчення здобутків української школи теорії режисури екранних мистецтв і конкретно в цьому контексті іï найяскравішого представника Володимира Горпенка, означає вивчення особливостей пошуків саме цієї школи, іiі традицій та спадковості, їі впливу на подальшу теорію екранних мистецтв, а також на сучасний стан екранних мистецтв в Україні, вивчення мистецьких пошуків i форм їх виявлення на місцевому грунті й з проєкцією у світ. Адже велика кількість учнів згаданої школи успішно реалізує себе на науковій, педагогічній, а також і на практичній, творчій ниві. Слід зауважити, що провідні українські режисери, визнані на світовому рівні, Мирослав Слабошпицький, Аркадій Непиталюк, Ірина Цілик та багато інших $є$ безпосередніми учнями і випускниками саме цієї школи. Важливо також у цьому контексті оцінити внесок кожного представника школи, зважити їх вплив і місце у діяльності української школи теорії режисури екранних мистецтв.
Mema cmammi. Отже, метою даного дослідження $є$ перша спроба визначення української школи теорії режисури екранних мистецтв як самобутнього явища, передусім як науково-теоретичної школи, яка, безумовно і неминуче, мала проєкції на мистецьку, педагогічну і творчу практику, та спроба оцінити окремі аспекти теоретичної діяльності Володимира Горпенка в контексті діяльності цієї школи.

Виклад основного матеріалу. Становлення школи відбувалося поступово, разом із становленням і розквітом роботи кафедри режисури телебачення. Поступово, за ініціативної діяльності завідувача кафедри Віктора Кісіна, зібрався колектив однодумців, переважно практиків екранних мистецтв (чомусь переважно практиків саме телебачення), які бачили необхідність у вивченні та теоретичному осмисленні й обгрунтуванні процесів сучасної екранної режисури. Досконале знання теорії режисури та теоретичне опрацювання даних супутніх наук стали надійним підгрунтям для переосмислення відомого й для створення власної моделі теорії режисури, яка виросла на українському грунті та базується на кращих традиціях української, радянської й західноєвропейської режисерської теорії і практики, увібравши в тому числі кращі традиції практичної і теоретичної режисури Леся Курбаса.

Слід зазначити, що в експериментальній теоретичній i практичній викладацькій діяльності у становленні школи важливе місце посідали представники суміжних мистецтв, прогресивні молоді науковці, теоретики, мистецтвознавці. Важливе місце в діяльності школи належить Вадимові Скуратівському (сьогодні вже доктору наук, професору, відомому українському мистецтвознавцеві, історику, літературознавцеві, публіцисту), Ользі Будниковій, мистецтвознавиці, блискучому знавцю образотворчого мистецтва та іншим видатним фахівцям своїх галузей і напрямів.

Однак за усім сказаним слід одразу обмовитись про те, що школа являла собою низку надзвичайно потужних сформованих теоретиків-особистостей, які працювали зі студентами у традиційний спосіб підготовки режисерів у тодішньому Київському державному інституті театрального мистецтва, кіно і телебачення імені Івана Карпенка-Карого - в системі майстерень. Висунуте поняття «школа» за цих обставин отримує певну своєрідність. 3 одного боку, підготовка у майстернях і сама робота майстерень розглядалася як показова конкурентна боротьба із застосування своїх методів і прийомів роботи кожного май- 
стра. 3 іншого - перехресне викладання майстрів у сусідніх майстернях надзвичайно підсилювало теоретичну базу підготовки майбутніх фахівців, загалом для школи це ставало тим базовим підгрунтям, на основі якого створювалась теорія режисури в Україні та розвивалася українська режисерська практика. Це уже з приватних бесід і переказів відомо, що представники школи вели палкі теоретичні дискусії, сперечалися один з одним, висловлювали свої аргументи і ледь не билися у відстоюванні власних ідей. Однак усе ж були загальні положення, з якими вони чи погоджувалися, чи, принаймні, не виступали із жорсткою критикою. Кожен з них був яскравим теоретиком, блискучим і цікавим викладачем, непересічною особистістю, талановитою, напрочуд обдарованою людиною з високими моральними вимогами і тонким мистецько-естетичним відчуттям. Проте явище школи було більше і ширше за дорогу їм кафедру телережисури, поєднувало всі ці пошуки та теоретичні й практичні студії.

Володимир Горпенко викладав на кінофакультеті з 1971 року, з 1994 по 2000 роки обіймав посаду декана кінофакультету (Тримбач, 2006). Та майстерня, яку він очолював, належала до кафедри режисури телебачення, і готував він режисерів саме телевізійного мистецтва (хоча це не завадило, приміром, М. Слабошпицькому, випускникові саме його майстерні, успішно реалізувати себе у кіно).

На доказ висловленої тези про те, що Володимир Горпенко належав до визначеної школи і працював у контексті діяльності цієї школи, можна послатися, зокрема, на центральну наукову працю В. Горпенка на ниві теорії режисури екранних мистецтв - багатотомну «Архітектоніку фільму: режисерські засоби і способи формування структури екранного видовища» 2000 року. Ця праця зовсім не випадково, а скоріше цілком логічно і навіть закономірно розпочинається присвятами багатьом людям. Серед присвят учителям на першому місці, певно, знаково значиться ім'я Михайла Верхацького, учня і натхненного послідовника Леся Курбаса. М. Верхацький викладав упродовж 1952-1973 років на театральному факультеті Київського державного інституту театрального мистецтва, кіно і телебачення імені Івана Карпенка-Карого, працюючи над підготовкою акторів, та, що найважливіше, створив надзвичайно потужну майстерню театральної режисури на базі того ж інституту. Як показав час, вихідці майстерні проявили себе не тільки на театральній ниві, вони гідно представляли майстерню у найрізноманітні- ших напрямах і проявах мистецтва режисури, а також і у супутніх мистецтвах. Особливого значення набула їх реалізація у сфері режисури екранних мистецтв: в кіно і на телебаченні. Зрештою, абсолютно незаперечний факт полягає у тому, що значна кількість представників школи були учнями саме М. Верхацького.

Повертаючись до багатотомної праці В. Горпенка, серед учителів зазначені також імена Вiктора Івченка і Сергія Герасимова. Це доволі символічне поєднання української педагогічної школи кінорежисури і російської кінорежисерської школи. Справді, якщо забігти дещо вперед, то Володимир Горпенко у своїй праці звертається до здобутків російської радянської кінорежисерської школи, але традиції української режисерської школи при уважному розгляді праці залишаються визначальним світоглядним орієнтиром, висхідною точкою розмірковувань. Обставини i природу формування В. Горпенка як режисера, а надалі й викладача і науковця в контексті традицій української режисерської школи достатньо детально висвітлив у своїй розвідці «Шлях у педагогіку екранних мистецтв Володимира Горпенка» О. Безручко (Безручко, 2010).

Нижче, у посвяті друзям згадуються: Віктор Кісін, Вадим Скуратівський, Вадим Чубасов. Звичайно, це були не лише друзі, а набагато більше - колеги, однодумці, соратники, переконані теоретики режисури, люди непересічного таланту й енциклопедичних знань, «без яких ця книжка не могла б з'явитися», як визначив їх внесок у появу дослідження сам автор. Відкритий діалог, дискусії і суперечки всередині цього кола (та нерідко і за межами його) стимулювали теоретичні, творчі та педагогічні зусилля не тільки його представників. Потенціал енергетичного заряду привертав професіоналів, згуртовував їх навколо спільної праці, мобілізував творчі зусилля багатьох людей, режисерів і педагогів, людей різних професій і сфер діяльності.

Слід віддати належне Володимирові Григоровичу. Саме в його фундаментальній грунтовній теоретичній праці зроблена спроба систематизації усіх базових векторів знання з режисури екранних мистецтв, виокремлених і акцентованих школою. Саме в його доробку - системний аналіз режисерської творчості на засадах базових підвалин, сформованих школою. Тому праці В. Горпенка являють собою величезну цінність як систематизовані і грунтовні дослідження процесів режисерської творчості. Також це - свідчення глибокої й копіткої роботи представників унікальної 
самобутньої української школи теорії режисури екранних мистецтв, а можливо, навіть і ширше, ніж тільки мистецтв екранних - мистецтв видовищних.

Слід зауважити, що саме Володимир Горпенко у своїй роботі зробив, можливо, найважливіше у контексті діяльності школи. Він зробив спробу системного вивчення явища екранного твору. Цю теоретичну розвідку він видав як наукову працю. Жоден $з$ інших представників школи не здійснив такого теоретичного осмислення процесу екранної творчості. Імовірно, якщо говорити точніше, то у кожного представника школи була своя місія у контексті діяльності цієї школи. Так от, місія Володимира Григоровича, певно, і полягала саме в систематизації загальних положень, в аналітичному переосмисленні величезних пластів наявного матеріалу з теорії екранної режисури та виробленні теоретичних засад теорії екранної режисури в контексті діяльності школи, відповідно до тих векторів, які цією школою визначалися фундаментальними підвалинами власне її існування.

Повертаючись до «Архітектоніки фільму» В. Горпенка. Певним чином знаковою стала і дата виходу цієї праці - 2000 рік.

2000 рік став переломним для існування школи. Наприкінці 1990-х відійшов у вічність іiі натхненник i, власне, активний ініціатор Віктор Кісін. Після 2000 відбулись серйозні зміни у житті університету, а відтак і самої кафедри телевізійної режисури. Теоретичні дискусії та пошуки дедалі більше втрачали видимий сенс. Життя ставило свої вимоги, ніби знецінюючи і нівелюючи набуте і досягнене, висуваючи чимбільш комерційний чинник як провідний життєвий принцип. Теоретичні праці та творчі дискусії представників школи ніби забулися, загубилися, відійшли у минуле... Однак досі продовжують працювати учні цієї школи, продовжують передаватися закладені цією школою традиції наступним поколінням студентів. I на сьогодні з'являється нагальна потреба говорити про здобутки цієї ніби забутої школи, аби виявити ті теоретичні і методологічні засади, що становлять базу української школи підготовки режисерів екранних мистецтв, і зрештою ствердити сам факт існування і плідної роботи цієї школи.

Іще останнім рядком у переліку присвят згадується онук Іванко, «без якого ця книжка не була б потрібна». Щемливе зізнання дідуся у любові онуку? Зрештою, який дідусь не розчулений своїм нащадком?.. Насправді, схоже, що тут приховано набагато більше. У цьому простому зізнанні глибокий зміст. Тут жевріє віра в те, що прийдешне покоління звернеться до цієї книги. У приведених рядках відчувається надія на онуків, які не лише гортатимуть сторінки цієї книги, а й наростять м'язи і хватку не тільки осягнути передане їм, а й переосмислити і впевнено рушити далі. Це - надія на прийдешні покоління, це - надія на розвиток і подальшу теоретичну розробку й практичне застосування всього того обширу, який гідно осмислили вони, представники української школи теорії режисури екранних мистецтв. Зрештою, існування школи багато в чому базувалося на спілкуванні зі студентською молоддю, на перевірці в аудиторії теоретичних пошуків, на прямому $\mathrm{i}$ відкритому діалозі з молодим поколінням заради зацікавлення, заради стимулювання, заради майбутнього поступу.

Повна назва найважливішої в науково-теоретичному доробку Володимира Горпенка системної праці $з$ теорії екранної режисури — «Архітектоніка фільму: режисерські засоби і способи формування структури екранного видовища». Уже саме формулювання назви дає вичерпну i достатньо повну відповідь на питання принципового підходу і розуміння екранного твору як мистецького явища. Важливо, що фільм у широкому розумінні всіх його проявів (об'єкт дослідження) одразу, вже у назві, визначається, навіть декларується, дослідником як екранне видовище. Особливого статусу поняття «видовище» отримує в контексті діяльності школи. Зокрема, представник школи, теоретик видовищної концепції, Віктор Кісін визначає видовище як спеціально організовану в часі та просторі публічну демонстрацію соціально значущої поведінки (Кісін, 1998, с. 6), i також створює загальну схему розвитку видовищної культури, в якій кіно і телебачення посідають важливе місце як уже мистецькі видовища (Кісін, 1998, с. 19-20). В. Горпенко наслідує концепцію видовищної культури, як представник школи, i пропонує «підхід до кінематографа не лише як до явища мистецтва, а як до особливого типу видовищності в цілому...» (Горпенко, 2000, автореф., c. 8). Таким чином, центром концентрації уваги тривалого і прискіпливого вивчення виступає, зрештою, вся режисерська екранна видовищна творчість в усій різноплановості й різноманітності іiі елементів і складових. Слід звернути увагу, що ані російська радянська школа кінорежисури 3 теоретичним узагальненням Львом Кулешовим (Кулешов, 1941) усіх їі кращих набутків, ані західні школи екранної режисури з їх практичним спрямуванням не брали за висхідну точку свого існування фундаментальні культурологічні категорії 
і чинники. Тут одразу слід зауважити, що працю української школи слід оцінювати у порівнянні зі здобутками, насамперед, російської радянської кінорежисерської школи (саме кінорежисерської, бо про значну школу теорії телевізійної режисури на той час іще не йшлося), на яку, як певним чином близьку і висновки якої більше теоретично розроблені та обгрунтовані з точки зору теорії режисури, орієнтувалися представники української школи.

Щодо загалом порівняння здобутків української школи зі здобутками і пошуками західноєвропейських та американських шкіл, то ця велика тема, безперечно, потребує окремого глибокого дослідження, оскільки йдеться про дещо різні підходи. Тут же слід зауважити, що надбання української школи теорії режисури екранних мистецтв були гідно відзначені західноєвропейськими колегами, про що свідчить факт запрошення представників школи для викладання окремих дисциплін, зокрема в Голландському інституті телебачення, в місті Хілверсум (Будникова, Наумова, 2016).

Повернемося до праці В. Горпенка «Архітектоніка фільму». Предметом дослідження постає режисура як мистецтво, як творчий процес. Дослідник звертає увагу на окремі засоби виразності фільму й аналізує їх як невід'ємні значимі складові цілісної неподільної структури. Так він сам визначає:

Предмет дослідження: в центрі уваги перебувають поетапність творення об'єкта (об'єктів) зображування певної типологічної природи, різнорідні механізми обробки (організації) цих об'єктів, узгоджувальне формування єдиної системи «одиниць мови», типологія способів спілкування автора (авторського колективу) з глядачем. (Горпенко, 2000, автореф., с. 4)

В. Горпенко у дослідженні видовищної специфіки кінематографа пропонує розглядати поступові фази його розвитку: видовищну і мистецького видовища. Такий підхід пропонує до екранної видовищної творчості в своїй найважливішій теоретичній праці «Режисура як мистецтво та професія» Віктор Кісін (Кісін, 1998). Такий само видовищний шлях у підході до екранних мистецтв обирає Вадим Чубасов при підготовці фахівців 3 режисури 1 року навчання у підручнику «Вступ до спеціальності “Кінотелемистецтво”» (Чубасов, 2005). На ранньому етапі видовищного поступу кінематографа (чи не до 1920-х років в Україні) останній стверджує свої позиції за рахунок атракціонної специфіки, а також намагання залучити засоби виразності уже цілком сформованих і розвинутих на той час у сталі форми мистецьких видовищ. 3 таких мистецтв найбільш впливовим на розвиток кінематографа виявився театр. Лише через кілька десятиліть по винайденні кінематографа усвідомлено починають формуватися специфічні, притаманні саме кінематографу, його особисті мистецькі засоби виразності. Цей процес, природно, не може бути швидким, відтак він триває чи не впродовж всього XX століття.

У системній праці «Архітектоніка фільму» Володимиром Горпенком

на відміну від традиційного почленування фільму за професійно-виробничим принципом сценарно-драматургічної, режисерсько-постановочної, акторсько-виконавської, зображально-декоративної, музично-звукової роботи структура фільму розглядається як двоєдиний акт розгортання праобразного і образного рівнів, дистанцію між якими реалізує міра і характер подоби. Це дає право включити у сферу “змістового” випромінювання відчуття естетичної насолоди від рівня майстерності митців, вважати його невід'ємною і цілком рівноправною складовою тексту художнього твору. (Горпенко, 2000, автореф., с. 4)

Таким чином, автор свідомо відходить від традиційного, запровадженого Львом Кулешовим (Кулешов, 1941) у російській радянській теорії режисерської творчості системного аналізу кінематографічного твору за виробничим чинником i пропонує своєрідний метод акцентованої уваги на окремих елементах режисерської творчості (які, власне, виходять уже за межі суто режисерської творчості й отримують власну професійну фахову специфіку), досліджуючи ці елементи в усій сукупності їх можливостей і характеристик. У цій точці відбувається принциповий розрив теоретичних пошуків В. Горпенка із теоретичними засадами російської радянської школи режисури кіно.

Для В. Горпенка надзвичайно важливі та актуальні в контексті режисерської творчості також і усі супутні явища, що визначають феномен фільму, - сума певних сформованих поглядів і настанов на мистецтво екранної режисури. Ці фантомні складові (що видимо не присутні у самому фільмі) визначають, проте, вектор діяльності автора-режисера. Його погляди і переконання формують систему виражальних засобів, методи і творчі підходи, а відтак визначають специфічний авторський стиль роботи, притаманний конкретному режисерові, конкретній творчій особистості.

Так, одним $з$ найсуттєвіших питань перед, власне, самим розглядом режисерських виражальних засобів для В. Горпенка постає питання зако- 
номірностей і механізмів організації авторського висловлювання $з$ точки зору предмету і матеріалу режисури аудіовізуальних мистецтв. Як справедливо були заклопотані визначенням даних категорій у різні часи В. Пудовкін (Пудовкин, 1974, c. 90-105), Л. Кулєшов (Кулешов, 1929), Д. Вертов (Вертов, 1966, с. 71-78), Ю. Лотман, Ю. Цив’ян (Лотман, Цивьян, 1994, с. 10-26), так і В. Горпенко зі всією відповідальністю поставленого ним самим перед собою завдання дошукується точного і єдиного визначення предмету і матеріалу режисури, та уже не суто кінематографа, а ширше - аудіовізуальних мистецтв. Зрозуміло, що і в цьому аспекті можна фіксувати розбіжності поглядів представників російської радянської кінорежисерськї школи (В. Пудовкіна, Л. Кулєшова, Д. Вертова) та української школи. Разом $з$ тим, В. Горпенко дискутує 3 представниками Тартусько-московської семіотичної школи Ю. Лотманом (Естонія) та семіотиком $\mathrm{i}$ теоретиком кіно Ю. Цив'яном (Латвія, США).

Насправді означення категорій предмету i матеріалу режисури для розуміння сутності кінематографа чи то телебачення надзвичайно важливі. Адже одна річ, коли матеріалом режисерської творчості, припустимо, у кіно, визначається плівка або зображення на цій плівці і звук, інша ж коли цим матеріалом виступає, скажімо, актор. В. Горпенко зауважує, що «ці питання актуальні передусім тому, що потрібні практичним творцям. Вони виступають складовою їхньої професійной, а відповідно й художнььӧ діяльності». (Горпенко, 2000, Т.2, с. 14). Численні спроби попередніх визначень цих понять, зрозуміло, не задовольняють В. Горпенка. Він прямує до пошуку власної відповіді своїм шляхом.

Передусім дослідник звертає увагу на першооснову творення екранної реальності на основі реальності життєвої. «Виходячи з конкретики аудіовізуальних мистецтв, логічно буде визнати, що вони мають ілюзорну природу, а матеріалом у них виступає трансформована у звукозображання предметна основа». (Горпенко, 2000, Т. 2, с. 15).

Таким чином, предметна основа $є$ первинним фізичним носієм створюваного екранного тексту. Однак В. Горпенко відразу зазначає, що характеристикою цієї предметної основи є ії ілюзорність: «одна з основних специфічних ознак предметної основи аудіовізуальних мистецтв полягає в тому, що вона, на відміну, скажімо, від театру, розрахована не на фізично реальний, а на ілюзорний часпростір-світ» (Горпенко, 2000, Т. 2, с. 15).

А власне «матеріалом аудіовізуальних мистецтв... має бути визнана предметна основа кадру, яка складається 3 двох типів елементів пластичного і звукового вигляду об'єкта та пластичної і звукової діï» (Горпенко, 2000, Т.2, с. 15).

Іще одним важливим компонентом у визначенні матеріалу аудіовізуальних мистецтв постає дія.

Ствердження примату дії як елемента загальної взаємодії спрямовує зусилля режисерського професіоналізму на відтворення живого багатства художнього змісту як процесу, здатного захопити глядача, вразити його, збудити, потрясти. (Горпенко, 2000, автореф., с. 13)

Отже, для В. Горпенка кінематографічний чи телевізійний твір передусім процес, а також зображення, визначальною характеристикою якого виступає також процесуальність.

Таким чином, за основу до визначення категорій предмету і матеріалу екранного аудіовізуального мистецтва В. Горпенком беруться категорії звуко-зображальності і дії. І кінематограф, і телебачення, оперують значно ширшими можливостями формування події. Навіть опосередковане створення події має у цих мистецтвах безліч варіантів. «Середовище, атмосфера, взагалі зображення предметного світу в кінематографі більш динамічно-процесні, ніж в театрі, а тому змістовно наповненіші і більш значущі» (Горпенко, 2000, автореф., с. 13). Зрештою, уже по завершенні свого великого дослідження автор дещо узагальнює свої пошуки і уже в авторефераті поданої до захисту дисертації на вчену ступінь доктора наук підсумовує, що

...матеріалом режисера в кіно-, телемистецтві $\epsilon$ вибудувана зі звуко-зображальних виглядів та звуко-зорової дії сукупність, яка виступає певною системою (структурою) складових елементів. Їх взаємодія і становить... матеріал режисерського мистецтва в кіно та телебаченні. (Горпенко, 2000, автореф., с. 13)

Оскільки кінематограф, як і телебачення мистецтва синтетичні (за їх визначальними ознаками відповідно до приналежності до видовищних мистецтв) і мисляться дослідником як результат втілення режисерської волі, базованої на всіх складових колективних зусиль, то одним 3 ключових точок у визначенні предмету і матеріалу цих мистецтв автор вочевидь бачить поняття сукупності. Саме звернення до сукупності як синтетичної характерності дає йому змогу обрати саме той науковий підхід до вивчення процесу режисерської творчості, який він обирає: за структурними елементами, що в кінцевому результаті складають цілісність екранного аудіовізуального твору. 
Таким чином, можна стверджувати, що вся праця Володимира Горпенка «Архітектоніка фільму» власне і присвячена пошуку відповіді на питання про предмет і матеріал аудіовізуальних екранних видовищних мистецтв. Він пропонуе грунтовну, глибоку розвідку у сутність цього матеріалу, а часом навіть у специфічні методи обробки цього матеріалу, власне, саме 3 огляду на таку його виняткову специфіку.

Наукову новизну дослідження визначає вперше запропонована концепція архітектоніки фільму як системи (структури) розгортання авторського ставлення до відтворюваного-відтвореного. (Горпенко, 2000, автореф., с. 4)

Висновки. Таким чином, уже 3 невеликого аналізу лише окремих аспектів теоретичної діяльності Володимира Горпенка зрозуміло, що його метод і положення відходять від тих традицій, що були прийняті в російській радянській школі теорії режисури. Дослідник піддає сумніву вже наявні висхідні позиції визначення предмету i матеріалу екранної режисерської творчості, обирає власний метод дослідження, грунтуючись на теоретичних розвідках представників української школи теорії режисури екранних мистецтв, своїх колег по роботі. Зокрема, він приймає і осмислює поняття екранного мистецького видовища і вкладає його у власну теоретичну концепцію. Таким чином, помітні зв'язки у теоретичних пошуках В. Горпенка та інших представників школи.

Попри невизначеність української школи теорії режисури екранних мистецтв, імена ії представників достатньо відомі у середовищі професіоналів-практиків, мистецтвознавців і теоретиків екранних мистецтв. Представники школи напрацювали величезний пласт матеріалу, який став надійним і витривалим фундаментом для формування власне теоретичних і методологічних традицій і положень школи. Також він став міцною теоретичною базою для підготовки режисерів-практиків (у тому числі переможців найпрестижніших світових кіно- і телевізійних фестивалів), теоретиків, педагогів і дав можливість кілька десятиліть після розпорошення представників школи по напрацьованому руслу провадити підготовку висококваліфікованих фахівців-режисерів, та, зрештою, і не тільки режисерів.

Визнання теоретичних надбань школи на міжнародному рівні можна пов'язати з фактами запрошення представників школи для викладання окремих дисциплін, зокрема в Голландському інституті телебачення, в місті Хілверсум, і плідної співпраці між навчальними закладами впродовж кількох років.

\section{Бібліографія}

Безручко, О. (2010). Шлях у педагогіку екранних мистецтв Володимира Горпенка. Мистецтвознавство Украйни. Київ: Музична Україна. Вип.11, с. 140-145.

Будникова, О.О., Наумова, Л.М. (2016). Віктор Борисович вчитель, колега, друг. В. Б. Кісін: режсисер, науковець, педагог: колективна монографія. Київ: Видав. центр КНУKiM, T. 1, c. 52-60.

В. Б. Кісін: режисер, науковець, педагог: колект. Монографія (2016-2021). Київ: КНУКіМ. (Т. 1-5).

Вадим Чубасов: режсисер, науковещь, педагог: колект. монографія (2014). Київ: КиМУ. Т. 1. 224 с.

Вертов, Д. (1966). Статьи. Дневники. Замыслль. Москва: Искусство, 320 с.

Горпенко, В.Г. (1995). Колір: підручник для студ. ін-тів театр. мистецтва. Київ: Київський ін-т театрального мистецтва ім. І. К. Карпенка-Карого. Ч. 1-4.

Горпенко, В.Г. (2000). Архітектоніка фільму: Режисерські засоби і способи формування структури екранного видовища: Автореф. дис. д-ра мистецтвознавства: 17.00.01; 17.00.04. Нац. муз. акад. України ім. П. І. Чайковського. Київ. 34 с.

Горпенко, В.Г. (2000). Архітектоніка фільму: режисерські засоби і способи формування структури екранного видовища: В 5 т. Київ: Київський держ. ін-т театрального мистецтва ім. І. К. Карпенка-Карого.

Горпенко, В.Г. (2000). Архітектоніка фільму: Режисерські засоби і способи формування структури екранного видовища. Київ: ДІТМ. Т. 2. 118 с.

Кісін, В.Б. (1983). Відеофільм. Перші кроки і перспектива. Мистеитвво кіно: Республіканський міжвідомчий науковий збірник. Київ: Мистецтво. Вип. 4.103 с.

Кісін, В.Б. (1998). Режисура як мистецтво та професія. Навчальне видання. Київ: Науково-освітній центр «АЕЛС-техно-логія», с. 82-95.

Кулешов, Л.В. (1929). Искусство кино (Мой опыт). Ленинград. 80 с.

Кулешов, Л. (1941). Основы кинорежиссуры. Москва: Госкиноиздат. $464 \mathrm{c.}$

Лотман, Ю., Цивьян, Ю. (1994). Диалог с экраном. Таллинн: Александра. 144 с.

Марченко, С.М. (2014). Відеофільм Вадима Чубасова «С. М. Ейзенштейн: уроки монтажу» як підручник 3 синтактики кіномови Ейзенштейна». Науково-практичні дослідження розвитку творчого прочесу в різних видах мистеитва (кінематограф, телебаченння, театр, меdia): колективна монографія. Київ: КиМУ. Т. 5. С. 20-65.

Наумова, Л.М. (2011). Про моїх учителів. Науковий вісник Київського національного університету театру, кіно $i$ телебачення імені I. К. Карпенка-Карого: Збірник наукових праць. Київ. Вип. 9. С. 254-263.

Наумова, Л.М. (2016). Окремі положення теоретичних пошуків В. Б. Кісіна. Поняття видовища В. Б. Кісін: режисер, науковець, педагог: колективна монографія / наук. ред.: О. В. Безручко. Київ: Видав. центр КНУКіМ. Т. 1. С. 127141.

Наумова, Л.М. (2019). Окремі положення теоретичних пошуків В. Б. Кісіна. Школа - Педагогічний метод. В. Б. Кiсін: режисер, науковещь, педагог: колективна монографiя / наук. ред.: О. В. Безручко; упоряд. С. І. Степаненко. Київ: Видав. центр КНУКіМ. Т. 4. С. 160-169.

Пам'ять. Майстер майстрів - Вадим Львович Чубасов: зб. ст. (2020). Дніпро: Арт-Прес. 75 с.

Пудовкин, В.И. (1974). Собрание починений в 3 т. Москва: Искусство. Т. 1.440 с.

Тримбач, С.В. (2006) Горпенко Володимир Григорович. Енциклопедія Сучасної України: електронна версія [веб-сайт] / гол. редкол.: І. М. Дзюба, А. І. Жуковський, М. Г. Желез- 
няк та ін.; НАН України, НТШ. Київ: Інститут енциклопедичних досліджень НАН України, 2006. URL: http:/ esu.com.ua/search_articles.php?id $=31502$

Чубасов, В.Л. (2005). Вступ до спеціальності «Кінотелемистецтво»: Навч. посібник. Київ: КиМУ. 484 с.

Bezruchko, O. (2017). The scientific and pedagogical activity of the ukrainian stage-director of the cinema and television V. G. Gorpenko. Художня культура. Актуальні проблеми. Київ. Вип. 13. С. 358-363 с.

\section{References}

Bezruchko, O. (2010). Shlyah u pedagogIku ekrannih mistetstv Volodimira Gorpenka [Vladimir Gorpenko's way to the pedagogy of screen arts]. Mystetstvoznavstvo Ukrainy. Kyiv: Muzychna Ukraina, 11, pp. 140-145. [in Ukrainian]

Bezruchko, O. (2017). The scientific and pedagogical activity of the ukrainian stage-director of the cinema and television V. G. Gorpenko. Khudozhnia kultura. Aktualni problemy. Kyiv, 13, pp. 358-363. [in Ukrainian]

Budnikova, O.O., Naumova, L.M. (2016). Viktor Borysovych vchytel, koleha, druh [Viktor Borisovich - teacher, colleague, friend] / V. B. Kisin: rezhyser, naukovets, pedahoh [V. B. Kisin: director, scholar, teacher: collective monograph]. Kyiv: KNUKiM, 1, p. 52-60. [in Ukrainian]

Chubasov,V.L.(2005).Vstupdospetsialnosti «Kinotelemystetstvo» [Introduction to the specialty «Cinematography»]: Textbook. Kyiv: KyMU. 484 s. [in Ukrainian]

Gorpenko, V.G. (1995). Kolir [Color: a textbook for students]. Kyiv: KDITM, 1-4. [in Ukrainian]

Gorpenko, V.G. (2000). Arkhitektonika filmu: Rezhyserski zasoby $i$ sposoby formuvannia struktury ekrannoho vydovyshcha [Architectonics of film: Directing means and ways of forming the screen spectacle structure]. Doctor's thesis. Kyiv. 34 s. [in Ukrainian]

Gorpenko, V.G. (2000). Arkhitektonika filmu: Rezhyserski zasoby $i$ sposoby formuvannia struktury ekrannoho vydovyshcha [Architectonics of film: Directing means and ways of forming the screen spectacle structure]. Kyiv: KDITM, 1-5. [in Ukrainian]

Gorpenko, V.G. (2000). Arkhitektonika filmu: Rezhyserski zasoby $i$ sposoby formuvannia struktury ekrannoho vydovyshcha [Architectonics of film: Directing means and ways of forming the screen spectacle structure]. Kyiv: KDITM, 2. $118 \mathrm{~s}$. [in Ukrainian]

Kisin, V. B. (1983). Videofilm. Pershi kroky i perspektyva [Videofilm. First steps and perspective]. Mistectvo kino, 4, pp. 82-95. [in Ukrainian]

Kisin, V. B. (1998). Rezhysura yak mystetstvo ta profesiia [Directing as an art and a profession. Educational edition]. Kyiv: AELS-Technology. 104 s. [in Ukrainian]
Kuleshov, L.V. (1929). Iskusstvo kino (Moj opyt) [The art of cinema (My experience)]. Leningrad, 80 p. [in Russian]

Kuleshov, L. (1941). Osnovy kinorezhissury [Fundamentals of film directing]. Moscow: Goskinoizdat. 464 s. [in Russian]

Lotman, Y., Tsivyan, Y. (1994). Dialog s ekranom [Dialogue with the screen]. Tallinn: Alexandra, 144 p. [in Estonia]

Marchenko, S.M. (2014) Videofilm Vadyma Chubasova «S. M. Eizenshtein: uroky montazhu» yak pidruchnyk Z syntaktyky kinomovy Eizenshteina» [Videofilm of Vadim Chubasov «S. M. Eisenstein: editing lessons» as a textbook on the syntax of Eisenstein's film language]. Naukovo-praktychni doslidzhennia rozvytku tvorchoho protsesu $v$ riznykh vydakh mystetstva (kinematohraf, telebachennnia, teatr, media). Kyiv: KyMU, 5, pp. 20-65. [in Ukrainian]

Pamiat. Maister maistriv - Vadym Lvovych Chubasov [Memory. Master of masters - Vadim Lvovich Chubasov]. (2020). Dnipro: Art-Press. 75 s. [in Ukrainian]

Naumova, L.M. (2011). Pro moikh uchyteliv [About my teachers]. Naukovyi visnyk Kyivskoho natsionalnoho universytetu teatru, kino i telebachennia imeni I. K. Karpenka-Karoho. Kyiv, 9, pp. 254-263 [in Ukrainian]

Naumova, L.M. (2016). Okremi polozhennia teoretychnykh poshukiv V. B. Kisina. Poniattia vydovyshcha [Some provisions of V. B. Kisin's theoretical research. The concept of spectacle] / V.B. Kisin: rezhyser, naukovets, pedahoh [V. B. Kisin: director, scientist, teacher].. Kyiv: KNUKiM, 1, pp. 127-141. [in Ukrainian]

Naumova, L.M. (2019). Okremi polozhennia teoretychnykh poshukiv V. B. Kisina. Shkola-Pedahohichnyi metod [Some provisions of V. B. Kisin's theoretical research. SchoolPedagogical method] / V.B. Kisin: rezhyser, naukovets, pedahoh [V. B. Kisin: director, scientist, teacher]. Kyiv: KNUKiM, 4, pp. 160-169. [in Ukrainian]

Pudovkin, V.I. (1974). Sobranie pochinenij v 3 t. [Collected works in 3 volumes]. Moscow: Iskusstvo, 1, 440 p. [in Russian]

Trymbach, S.V. (2006) Gorpenko Volodimir Grigorovich. Entsyklopediia Suchasnoi Ukrainy [Encyclopedia of Modern Ukraine]: electronic version [website] / goal. editorial board: I. M. Dzyuba, A. I. Zhukovsky, M. G. Zheleznyak and iн.; NAS of Ukraine, NTSh. Kiev: Institute of Encyclopedic Sciences of the National Academy of Sciences of Ukraine, 2006. Retrieved from: http://esu.com.ua/search_articles. php?id=31502 [in Ukrainian]

V. B. Kisin: rezhyser, naukovets, pedahoh [V. B. Kisin: director, scientist, teacher: collective monograph]. (2016-2021). Kyiv: KNUKiM, 1-5. [in Ukrainian]

Vadym Chubasov: rezhyser, naukovets, pedahoh [Vadim Chubasov: director, scientist, teacher: collective monograph]. (2014). Kyiv: KyMU, 1. 224 s. [in Ukrainian]

Vertov, D. (1966). Statt'i. Dnevniki. Zamysly [Articles. Diaries. Conceptions]. Moscow: Iskusstvo, 320 p. [in Russian]

\section{Larysa Naumova \\ Volodymyr Gorpenko's screen directing theory in the context of the Ukrainian screen arts directing theory school activities}

Abstract. The article studies the phenomenon Ukrainian screen arts directing theory school. It was created and developed in 1980 - 1990 at the Kyiv I. K. Karpenko-Kary Theatre, Cinema and Television University. The school has created a base for the training of directors-practitioners, teachers and screen arts theorists. Screen directing theorist, teacher Volodymyr Gorpenko had an important place in this school. His work on the theory of screen arts directing shows some of the school's activities.

Keywords: Ukrainian screen arts directing theory school, the theory of directing, screen arts, Volodymyr Gorpenko, screen directing. 


\section{Наумова Лариса Николаевна}

Теория экранной режиссуры Владимира Горпенко в контексте деятельности украинской школы теории режиссуры экранных искусств

Аннотация. В статье исследуется феномен школы теории экранных искусств, возникновение и плодотворная деятельность которой приходились на $1980-1990$ годы в стенах Киевского университета театрального, кино и телевизионного искусства им. И. Карпенка-Карого. Школа стала серьезной базой для подготовки режиссеров-практиков, педагогов и теоретиков экранных искусств. Особое место в этой школе принадлежало теоретику экранной режиссуры, педагогу Владимиру Горпенку. Его работы по теории режиссуры экранных искусств отображают некоторые направления деятельности школы.

Ключевые слова: школа теории режиссуры экранных искусств, теория режиссуры, экранные искусства, Владимир Горпенко, режиссура. 